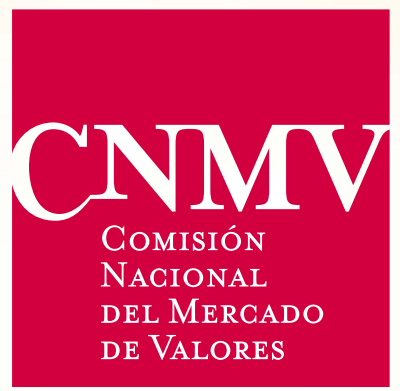

High-yield bond market: features and risks of a growing market

María del Rosario Martín Martín

Documentos de Trabajo $\mathrm{N}^{\circ} 61$ 



\section{High-yield bond market: features and risks of a growing market}

María del Rosario Martín Martín (*) 
María del Rosario Martín Martín is a member of the Research, Statistics and Publications Department, CNMV.

The opinions in this Working Paper are the sole responsibility of the authors and they do not necessarily coincide with those of the CNMV.

The CNMV publishes this Working Paper Series to enhance research and contribute towards greater knowledge of the stock markets and their regulation.

The CNMV distributes its reports and publications via the internet at www.cnmv.es

(C) CNMV. The contents of this publication may be reproduced, subject to attribution.

María del Rosario Martín Martín pertenece al Departamento de Estudios, Estadísticas y Publicaciones de la CNMV.

Las opiniones expresadas en este documento relejan exclusivamente el criterio de los autores y no deben ser atribuidas a la Comisión Nacional del Mercado de Valores.

La Comisión Nacional del Mercado de Valores, al publicar esta serie, pretende facilitar la difusión de estudios que contribuyan al mejor conocimiento de los mercados de valores y su regulación.

La Comisión Nacional del Mercado de Valores difunde la mayoría de sus publicaciones a través de la red Internet en la dirección www.cnmv.es

(C) CNMV. Se autoriza la reproducción de los contenidos de esta publicación siempre que se mencione su procedencia.

ISSN (edición electrónica): 2172-7147

Maqueta: Composiciones Rali, S.A. 


\section{Summary}

Speculative-grade debt, in other words, debt rated below BBB or unrated debt, has had significant growth recorded in recent years, driven, among other factors, by its higher profitability compared with other investment assets, its relatively low default rates and the diverse economic sectors to which the issuers belong, which converts these securities into an attractive option for portfolio managers. The interest in these types of securities, also known as high-yield bonds, has moved somewhat to secondary markets, where the number of transactions has also increased, pushing up prices. All of this is generating a debate on the sustainability of the growth of this market. So, while some agents argue that in recent years the market for speculative debt has matured, others express doubts about whether the risks taken by investors by incorporating these high-yield, high-risk assets into their portfolios is being correctly assessed. The discussion is occurring at a time when there is clear interest at a European level in developing corporate debt markets as a source of additional corporate funding so businesses can reduce their reliance on bank financing. Given this background, this paper reviews the recent trends and the main characteristics of the markets for high-yield bonds and analyses the risk factors that could jeopardise their development and consolidation as a feasible source of funding for the real economy. 



\section{General index}

1

Introduction

Characteristics and recent developments in speculative-grade debt

2.1 Characteristics of high-yield securities

2.2 Factors that have driven the high-yield market

2.3 A look at the Spanish bond market

3 Specific features of the secondary market for high-yield bonds

\begin{tabular}{llr}
\hline 3.1 & Characteristics of secondary market transactions & 25
\end{tabular}

\begin{tabular}{llr}
\hline .2 & Behaviour of high-yield bonds in secondary markets & 28
\end{tabular} 



\section{Index of Figures}

\begin{tabular}{llr} 
FIGURE 1 & Issuance of high-yield bonds: 2000-2014 & 18 \\
\hline FIGURE 2 & Issuers and purchasers of high-yield bonds in 2014 & 19 \\
\hline FIGURE 3 & Profitability of US speculative bonds versus European speculative bonds & 20 \\
\hline FIGURE 4 & Outstanding balances and default rates of speculative-grade debt & 21 \\
\hline FIGURE 5 & Sources of financing for Spanish companies & 22 \\
\hline FIGURE 6 & Rating of the issues by Spanish companies-July 2014 & 23 \\
\hline FIGURE 7 & Issue of speculative debt by sector in 2014 & 23 \\
\hline FIGURE 8 & Evolution of the performance of European and US high-yield bond indices & 28 \\
\hline FIGURE 9 & Volatility of US corporate debt: 2004-2014
\end{tabular}

\section{Index of Tables}





\section{Introduction}

The delicate financial situation of the banking sector as a result of the crisis, combined with the requirements for higher solvency and liquidity levels for banks in line with the prudential framework provided by Basel III, has led to a decrease in the funding these entities traditionally granted to the real economy. With less credit available, companies are increasingly turning towards the debt market. The growth of this market points to a structural change in the way businesses are financed, especially in economic areas traditionally dependent on banking, such as Europe.

The approach made by businesses to markets has been fuelled by the rising demand for corporate debt among investors. After several years during which security was the priority of their investment strategies, they are now beginning to look for assets that provide them with higher returns.

The debt markets have benefited from this confluence of interests between issuers and investors and they have experienced significant growth in recent years. The expansion not only affects the issues that receive a credit rating within the so-called investment grade (grades ranging from AAA to BBB-), but also the debt classified as speculative grade or high yield (that rated below BBB as well as unrated issues).

It is not the first time that speculative debt has experienced such a rapid growth. In the eighties, these types of securities acquired great prominence due to booming LBO (leveraged buyout) operations in which small businesses, some of which were created ex-profeso, obtained the resources to buy much larger companies, in financial difficulties but with solid assets, by issuing high-yield bonds. After the acquisition, the bonds were amortized using those assets.

The economic slowdown in the nineties saw many of these companies go bankrupt or become unable to meet the financial obligations arising from these securities and a large number of investors were affected. Thereafter, this market segment was affected by a certain stigma as it was considered to contain only low credit quality, high-risk securities linked to markedly speculative operations.

In recent years, speculative-grade debt markets are experiencing a new golden age. This document lists the items that are promoting this new growth and analyses the risks associated with it. 
Unlike in the eighties, the current issues are not linked to LBO operations ${ }^{1}$ but reflect the need to refinance companies in the restricted bank credit environment referred to above. In general, a profitability above that offered by other financial options together with the low default rates displayed by the issuers in recent years, the diversity of economic sectors in which investment opportunities can be found and the perception that the secondary market for these securities is now more active than in the past, all make high-yield securities appear an attractive option for managers of financial asset portfolios.

This paper is organized as follows: the second section reviews the main characteristics of high-yield securities, as well as developments in the primary market in recent years, including the issuance activity of Spanish companies. The third section deals with the characteristics of secondary markets for speculative debt. The fourth section highlights the risk factors that the current growth of these securities may be introducing into the financial system as a whole. The paper closes with a section on conclusions. 


\section{Characteristics and recent developments in speculative-grade debt}

Strategies designed by companies to meet their financing needs are varied and evolve according to the circumstances in which they find themselves. In principle, bank credit and fixed and variable income markets are presented as important sources of funding.

It is also true that, in some countries, the business sector is traditionally more dependent on the banks than in others. In Spain, $78 \%$ of business finance is obtained through banks, a figure that compares with $45 \%$ in France and $30 \%$ in the United States. In these latter countries, the debt markets acquire an important position for companies when seeking money to finance their daily activity or growth projects.

However, fixed income markets are not available to all types of company. Small and medium enterprises, hereinafter SMEs, still use banks as their major financiers due to the size of their transactions and/or the local nature of most of their trade relations. However, bank financing of these types of companies has been greatly reduced in recent years, mainly due to the deleveraging of the banking sector and the regulatory changes that have made lending to this business segment, which is riskier and less liquid than the rest, more expensive in terms of capital consumption.

Thus, size provides one of the first filters for accessing fixed income markets, and even more so if a company intends to access this type of financing in international markets. There is a fixed cost for accessing these markets which is easier for large firms to absorb than it is for the smaller ones; once this is overcome, the average cost of an issue decreases. Generally, it is considered that the cost and the average size of each operation in these markets is beyond the scope of companies with a turnover below 500 million euros ${ }^{2}$.

$\%$ Companies active in the debt market

\begin{tabular}{lrr} 
Size in annual turnover & European Union & United States \\
\cline { 2 - 3 } Under 500 million dollars & Less than 5\% & $5-10 \%$ \\
\hline Between 500 and 5,000 million dollars & $30-40 \%$ & $50-60 \%$ \\
\hline Between 5,000 and 20,000 million dollars & $70-80 \%$ & $90-100 \%$ \\
\hline Over 20,000 million dollars & $100 \%$ & $100 \%$ \\
\hline
\end{tabular}

Source: AFME and O. Wyman (2013), «Unlocking funding for European investment and growth».

2 AFME and O. Wyman (2013) 
Table 1 illustrates the increased participation of US SMEs in the debt markets, compared with their European counterparts. However, access to the markets by smaller European companies has increased in recent years; in 2013, the operations performed by companies with EBITDA under 100 million dollars tripled, accounting for $18 \%$ of the total issued. Furthermore, the issues of companies with EBITDA under 50 million dollars reached a maximum when it reached 2,000 million dollars 3 .

Besides size, another obstacle to accessing the debt markets is the continuing decline in credit ratings which numerous business groups have suffered. Among the factors that have led to lower corporate ratings are the deterioration of the results and expectations of some companies caused by the economic depression in certain countries, the high leverage assumed by many companies during the years of economic growth and the effect prompted by the drop in sovereign ratings ${ }^{4}$. According to data published by Fitch Ratings 5 , $40 \%$ of the ratings of non-financial companies are at the BBB level and only around $20 \%$ are above this rating.

Following the financial crisis, many of these companies, SMEs or with low credit ratings, found it difficult to refinance their bank debt and the speculative debt markets offered a feasible alternative. Of the issues undertaken during the first half of $2014,28 \%$ were used to replace expired issues, $13 \%$ to replace bank debt and $13 \%$ were for other refinancing purposes ${ }^{6}$.

The dynamism of the speculative debt market, benefits companies in several ways. First, it provides access to funding, sometimes under better conditions than banks are currently willing to offer. Also, the prevalence of fixed rates on these securities, facilitates the control of financial flows and the current scenario of low interest rates, resulting in significant savings. Lastly, they diversify their sources of funding and reduce their dependence on banks for debt management.

\subsection{Characteristics of high-yield securities}

Despite being fixed income securities, high-yield bonds have a number of specific features which are due largely to the nature of the issuer of these securities, and sometimes also to the type of investors that incorporates these financial assets in their portfolios. Thus, these products are designed individually and it is difficult to speak of a standardized product in this market segment.

Throughout this section we shall analyse the various economic aspects of these securities: the maturity, the type of remuneration, the order of priority they take with-

3 According to data released by Moody's rating agency available at https://www.moodys.com/research/ Moodys-More-smaller-European-companies-issuing-high-yield-bonds--PR 284489?WT.mC id=NLTITLE_YYYYMMDD_PR_284489\%3c\%2fp\%3e

4 In this regard, see the analysis of the cascading effects prompted by the decline in the credit rating of Spanish sovereign debt, shown in Table 5 of the «Report on the markets and their agents: situation and prospects» published in the CNMV Bulletin for the third quarter of 2012

5 See FitchRatings (2014). The Cost of Economic Recovery: Rating Stabilisation but «BBB» the New Form.

6 Source: S \& P Capital IQ / LCD, available at http://www.highyieldbond.com/primer/\#!the-leveraged-loaninvestor-market 
in the issuer's obligations, additional guarantees they usually incorporate and, finally, the set of rules by which the issuer and the investor agree on a series of actions to be taken in the event that certain scenarios occur, known as covenants.

\section{Maturity}

Most of these securities are long-term financial instruments7. Specifically, $70 \%$ of the issues made in 2014 had lives of between 5 and 10 years ${ }^{8}$.

In general, high-yield bonds are issued with a single maturity date on which the investor is repaid the principal of the bonds. However, it is common for the issuer to reserve an option for early repayment after half the security's life has elapsed. Investors are interested in those structures which incorporate an initial period without a right to early repayment, since in these cases they can be assured of a minimum level of profitability and can eliminate the risk of reinvestment on dates too close to the initial outlay.

The growing demand for this type of security in recent years has allowed issuers to incorporate clauses that provide greater flexibility when deciding whether to keep a specific issue in circulation or not. In particular, the inclusion of clauses that enable the issuer to make prepayments during periods in which this possibility was not initially provided for has increased. Thus, most high-yield bonds issued in 2012 included the possibility that the issuer could repurchase the bonds even in periods that had not been provided for, on payment of a higher return?.

Another mechanism for early recovery of part of the debt issued is the partial repayment, typically around $35 \%$ of the volume initially issued and also outside the authorised dates, using funds that the issuer has obtained through capital increases ${ }^{10}$. The investor benefits from this because the issuer is strengthening the company equity which may result in an improvement in the credit rating of the bonds which, in turn, affects the quality of the investor's portfolio.

\section{Interest rate}

The payment of a fixed coupon is the most common form of remuneration for these bonds, although variable interest rates linked to a reference interest rate such as the EURIBOR or LIBOR plus a margin can also be found.

7 Numerous international organizations, such as the Financial Stability Board and the World Bank, define longterm financing as that for which the maturity period exceeds five years. From an accounting point of view, business enterprises must consider all maturities for a period exceeding 12 months as long-term funding.

8 Source: AFME

9 The amount of such compensation usually comprises: an additional $10 \%$ of the nominal, plus the current value of all interest that the investor would have earned from the date of prepayment to maturity increased by around 50 basic points.

10 This type of operation is known as equity clawback 
An alternative to the traditional coupon is payment in kind or a combination of cash and bonds. The so-called PIK or PIK-toggle ${ }^{11}$ offer benefits to the issuer because they allow a postponement of the need to raise the cash required to meet the periodic payments. This is of interest from the point of view of managing cash flow. This kind of issue, which was practically residual in 2010, reached 12,000 million dollars in the US in 2013. During the first half of 2014, issues for 8,000 million dollars were recorded, more than double the amount recorded in the first half of the previous year ${ }^{12}$.

The schedule of payments on the bonds is fixed according to the issuer's treasury forecast but, to ensure the success of an issue, the interest of potential subscribers must also be taken into consideration. Bonds with fixed interest rate usually pay out every six months, while variable rate bonds are usually paid quarterly.

\section{Subordination}

Typically, this kind of security adopts a subordinate position in the payment priority order. Even when not issued explicitly as subordinated securities, the payment collection priority can be conditioned by a variety of factors. For example, bonds issued by the companies heading up corporate groups, which are usually purely share holding companies, are structurally subordinate in relation to similar securities issued by companies that effectively carry out the groups business activity and, consequently, they recover unpaid amounts later. This is because the debt of the operating companies of the group usually contains restrictions for payments to its parent company, so that the latter would not have access to either cash or assets in the hands of the former. Moreover, if an operating company is liquidated, it must pay all amounts owed to its creditors, both ordinary and subordinate, before distributing the remainder, if any, to its shareholders.

\section{Additional guarantees}

Although most high-yield bonds are issued without any safeguards other than the assets of the issuer, it is possible to find bonds further supported by one or more companies belonging to the same group or by specific assets. According to a study ${ }^{13}$ conducted among 939 operations executed between 2011 and 2013, 54\% of the guaranteed bonds issued had primary guarantees, $25 \%$ had secondary guarantees and $21 \%$ had devised a scheme in which primary guarantees were attached to certain assets and secondary guarantees to others.

11 The name corresponds to the acronym, paid in-kind. PIK-toggle are those which alternate cash payment and payment in bonds.

12 According to data published by S \& P Capital IQ on 30 June 2014. An example of this type of security is the issue made by Befesa in 2013. This Spanish company issued PIK-toggle type bonds worth 150 million euros that matured in 2018 at an interest rate of $10.5 \%$ if paid in cash and at $11.25 \%$ if paid in additional securities.

13 Proskauer (2014), «Global High Yield Study» available at http://www.womensprivateequitysummit.com/ pdf/2014_Global_High-Yield_Bond_Study.pdf 


\section{Covenants}

The investment risk profile of high-yield bonds and the greater probability of default mean these securities, more than other corporate debt with higher credit ratings, incorporate a set of rules in which the issuer and the investor agree a series of action clauses, known as covenants. The purpose of these clauses is to protect the bondholders from actions that might harm their interests.

In particular, it is common to include compliance with certain ratios that limit the issuer's borrowing capacity ${ }^{14}$. Also, with the aim of avoiding any action that could impair the value of the company, limitations on the sale of assets are usually established unless the money is reinvested in the company within a certain period of time, usually less than one year or, alternatively, the company offers to repurchase the bondholders' securities.

The restriction of payments to shareholders in the form of dividends, corporate purchases, investments or cash outflows of any type from the security issuer's treasury is also often required by potential investors. Specifically possible payouts are usually limited to between $15 \%$ and $20 \%$ of EBITDA. This not only aims at preventing non-compliance with the timetable of debt, but also at altering the priority of debt holders in the operating companies in favour of debtors of other companies belonging to the consolidated group.

The order of priority for the payment of high-risk securities, as is the case, is essential for investors, which is why they seek to restrict the issuer's ability to use specific assets to guarantee any other debts issued by the company or by any other company belonging to the group. Another way to protect the position in the cascade of payments is to include negative pledge provisions; with these, an ordinary creditor receives some additional collateral if the managers of the company decide to issue new debt.

Situations involving change of control or merger of a company are often also taken into account, as investors try to prevent the new corporate framework ceasing to respond to the obligations entered into by the previous corporate structures. Therefore, it is common to include an option for the investors to sell the bonds to the company if the latter changes its controlling shareholders or, alternatively, the bondholders can directly abort any attempt to merge with other companies unless the company resulting from the merger expressly states its willingness to assume the obligations arising from that debt and investors can check that it is able to do so by compliance with certain pro forma debt ratios.

The vast majority of issues include a suspension or cancellation covenant that allows the removal of some of the restrictions mentioned above when the issuer achieves an investment-level credit rating.

In addition to the covenants mentioned so far, there are other, lesser used ones that investors or issuers may consider to be either more or less important when consider-

14 Among the most common measures are interest coverage and leverage. 
ing an operation of this kind. In all cases, the issuers always try to achieve maximum flexibility and secure extensive control over the management of their company, while bondholders seek to keep the company within the parameters of solvency and liquidity that enable the debtor to face its financial commitments and protect the bondholders' investment.

Under no circumstances can the covenants give the bondholder any significant control over the management strategy of the company, nor contribute to the stagnation or decline in value of the company.

\subsection{Factors that have driven the high-yield market}

Despite the risk inherent in such securities, the volume of issues has experienced a significant increase in recent years. For example, between 2009 and 2014, issues of high yield bonds at a global level, doubled from 180,099 million euros to 383,696 million euros.

The most important market was that of the USA which, in 2014 , generated $48.8 \%$ of the total (see Figure 1). Nevertheless, the high-yield segment remains relatively small - last year it represented only 10\% of all fixed income securities issued.

Issuance of high-yield bonds: $2000-2014$

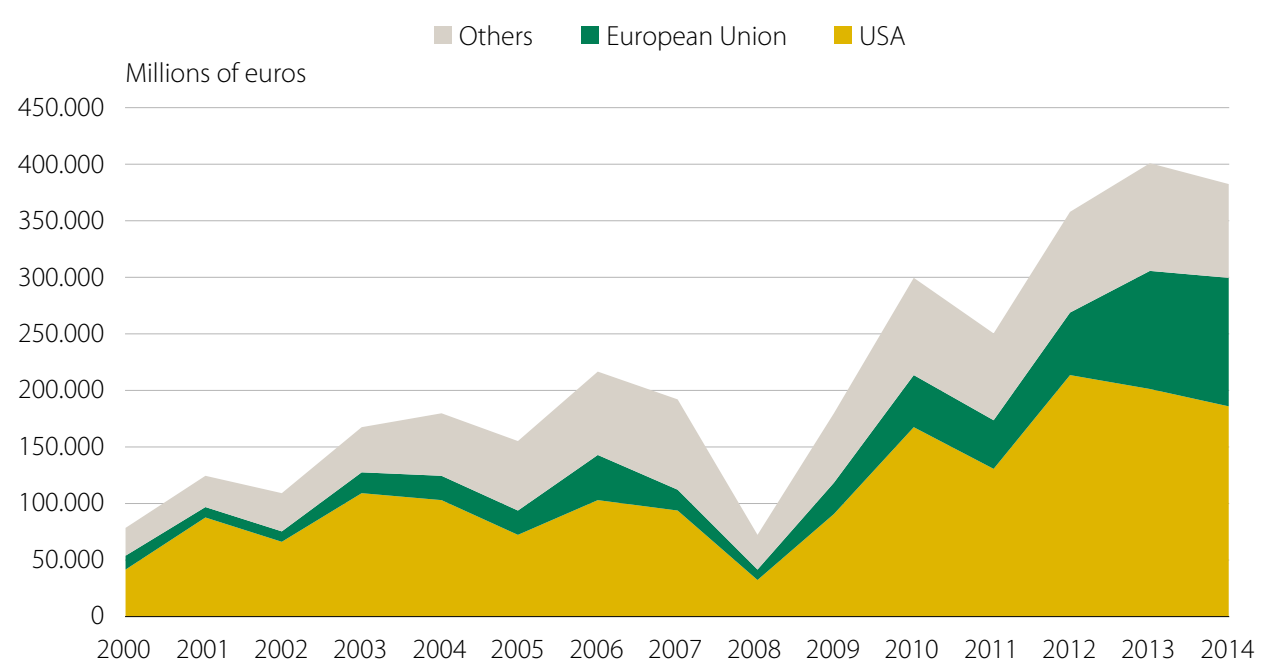

Source: Dealogic.

Apart from the financial sector, some of the most active economic sectors in these markets are telecommunications and energy, with technological and pharmaceutical companies also being worth a mention (see Figure 2). An important part of these companies is characterized by their intensive use of capital, such that debt markets are essential for diversifying their sources of financing. It must also be remembered that in recent years company expansion expenditures have been restricted, so many are taking advantage of the remainders and the growing demand for corporate debt, especially speculative-grade debt, to restructure their fi- 
nancing schemes, replacing bank debt or replacing securities issued in previous years by new debt.

It is common for companies to conduct this type of operation through companies whose corporate purpose is focused on managing the financial needs of the group, either raising funds in financial markets or distributing them among the various companies according to their needs at the time. In addition to reducing bank financial expenses, one of the benefits of centralized treasury management is the ability to negotiate better prices for the debt issued, thanks to higher issuance volumes.

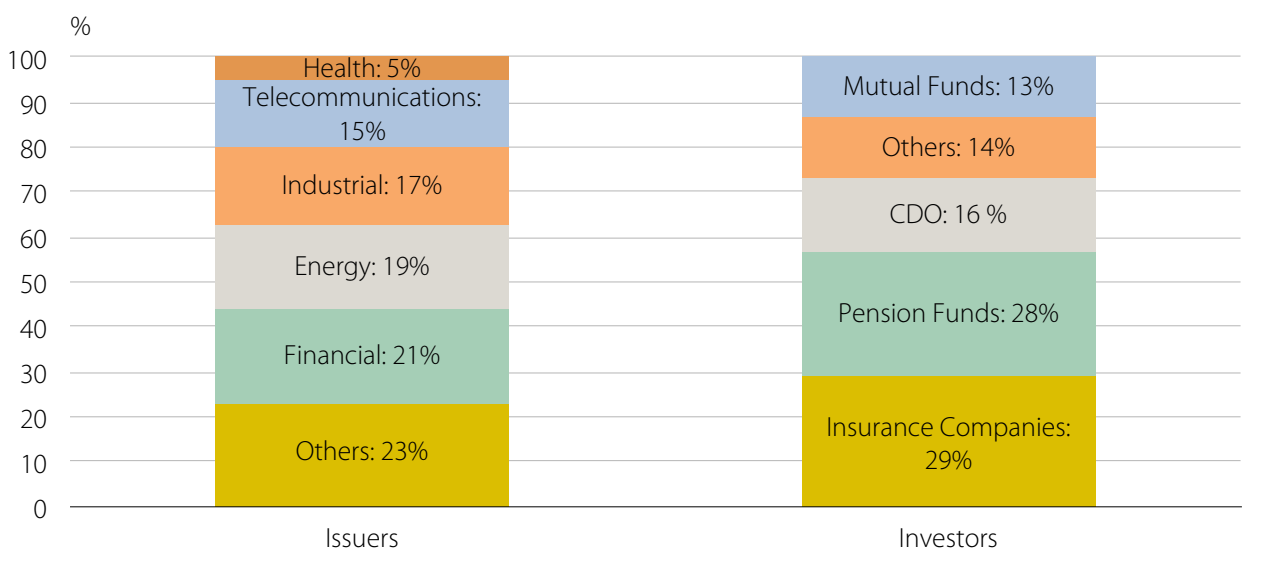

Source: Dealogic.

With regard to buyers, insurance companies and asset portfolio managers are positioned as the main investors in these operations. The most common way to acquire high-yield bonds is by participating in private placements made by issuers ${ }^{15}$.

Unlike the USA, where the main economic agents involved in this market - professional investors (hedge funds, investment funds, insurance companies, etc.) and the intermediaries in this type of operation (coordinators, underwriters, book runners, etc.) - have unified and standardised the documentation and processes for these operations, in Europe the situation is different. To correct this deficiency, in June 2014, at the request of the main professional associations of financial markets $^{16}$, The Pan-European Private Placements Working Group was created with the aim of promoting the creation of a European market for private placement of

15 Private placements of securities appear in the legislation, usually within the scope of anything that is not a public placement. For example, the Spanish legislation Royal Decree 1310/2005, Article 38.1 which lists the characteristics of those operations that are not publicly traded securities. Private placements of securities are exempt from the registering of a prospectus and making it available to the public at the time of sale and subsequently from preparing public information periodically throughout their life.

16 The associations involved in this working group are: International Capital Market Association (ICMA), Association for Financial Markets in Europe (AFME), Association of British Insurers (ABI), European Private Placement Association (EU PPA), French Euro Private Placement (Euro PP) Working Group and Loan Market Association (LMA) 
corporate debt. As a starting point, the group will use the work undertaken for the creation of Europe Private Placements (Euro PP) conducted by different participants in the French financial industry. The Euro PP market began operating in early 2013 and in that year recorded operations to the value of 7,000 million euros. A Euro PP may take the form of a bond or loan, usually without credit rating and, although it may be transferable, it is acquired with the intention of holding until maturity. It is a market in which the issuer negotiates the terms of the debt with a limited number of investors but with a specific contractual framework based on best international practices, self-regulation and the adoption of common practice in financial markets.

\section{Attractive returns for issuers and investors}

The returns offered by speculative debt is one of the main attractions for both investors and issuers.

The weighted average rate offered by European high-yield bonds in 2014 was $5 \cdot 59 \%$, which contrasts with the returns offered by the public debt of countries like Germany and Spain which, in December 2014, was placed in bond markets for five years at $0.24 \%$ and $0.9 \%$, respectively ${ }^{17}$.

The pressure of demand for these securities in markets, driven largely by the expansionary monetary policy measures of the European Central Bank, has allowed issuers to lower the interest rate offered on their bonds (the average interest rate of issues in Europe fell by one percentage point in 2014). Despite this decline, the price of European speculative debt has remained above US debt in the last two years (see Figure 3), which is why many European issuers, especially banks, have opted to issue in dollars for US investors.

\section{Profitability of US speculative bonds vs European speculative bonds}

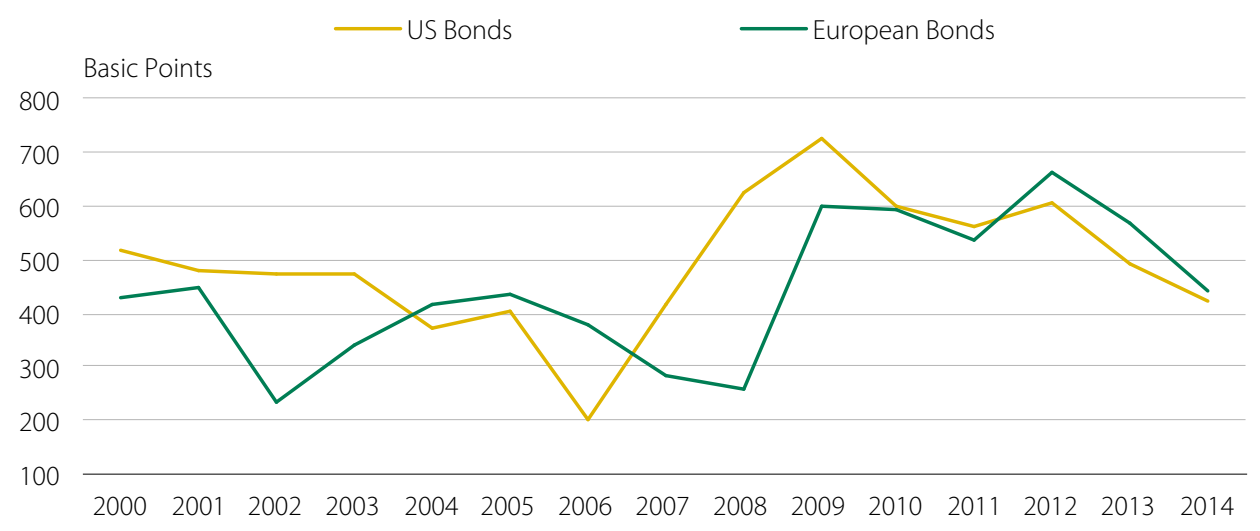

Source: Dealogic.

17 Source: Scope Ratings, German Public Treasury and Spanish Public Treasury. 
The search for profitability has also led investors to explore less traditional markets such as the Asian market where, for example, Chinese corporate bonds have paid up to 1.2 percentage points more than US high-yield bonds.

\section{Low default level}

Another factor that is encouraging the growth of the speculative debt market is the low level of default recorded by high-yield bonds in recent years; specifically, in 2013, European bonds recorded a default rate of 3.3\% and American bonds $2.12 \%$.

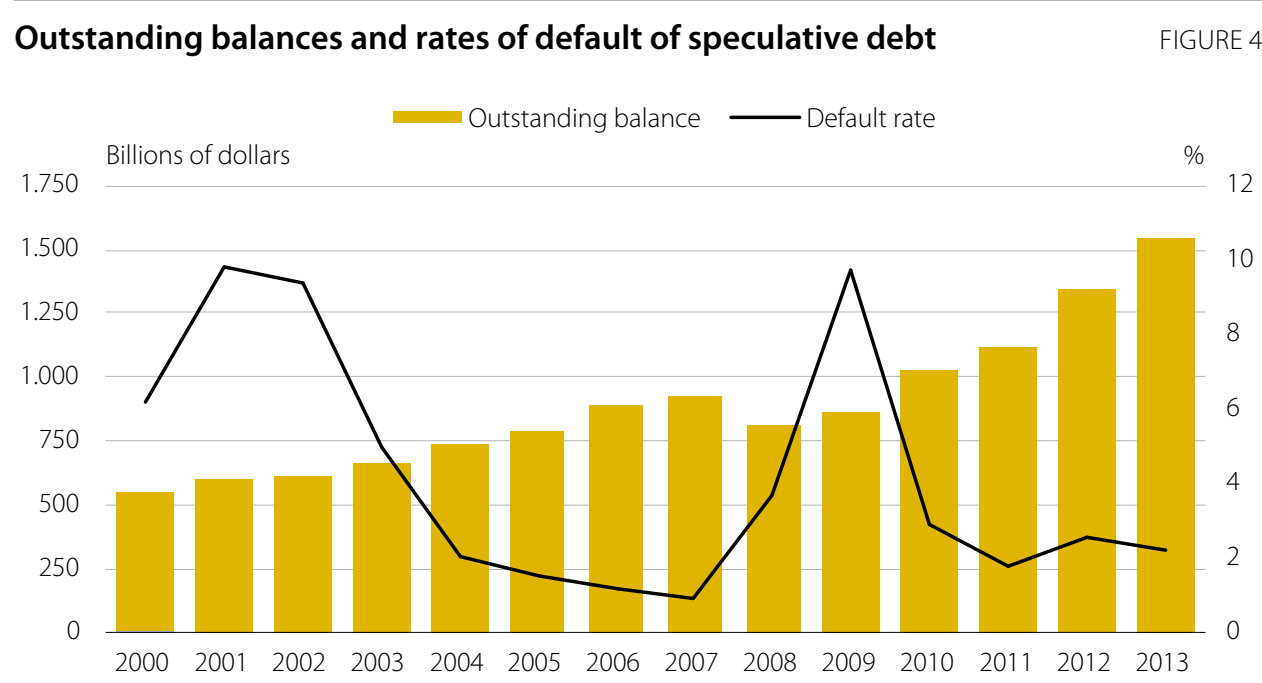

Source: Dealogic y Standard\&Poors.

In an economic environment in which the most developed economies - mainly the United States, the European Union and Japan - begin, in some cases, to show signs of stabilization and clear signs of recovery in others, investors expect many companies to improve their financial expectations and be rewarded with increases in debt rating, this would improve the quality of investment portfolios maintaining high levels of profitability.

This favourable combination of risk and return is encouraging the entry of new investor profiles; therefore, the high-yield bonds that even a few years ago were acquired only by investors who specialized in exposures to high-risk securities such as hedge funds, begin to be present in portfolios of more conservative investors such as pension funds and insurance companies. Among the benefits that portfolio managers brandish to defend taking speculative positions in debt include: obtaining yields, portfolio diversification and the coverage that this type of asset offers against potential interest rate rises or inflation.

\subsection{A look at the Spanish bond market}

The restructuring process that has affected a significant part of the Spanish financial sector has added to the factors that, in general, have caused a significant decline in bank lending to the real economy. According to data published by the 
Bank of Spain, bank financing for productive activities fell by $34 \%$ between December 2010 and September $2014^{18}$. Therefore, and as in other countries, the Spanish business sector has sought alternatives to this source of funding. One of these has been to turn to international capital markets to replace mature bank debt. This occurs mainly in larger companies but there is also a drag effect on other smaller companies that are not so accustomed to international financial environments.

Financing of Spanish companies: fixed income issues and bank loans FIGURE 5

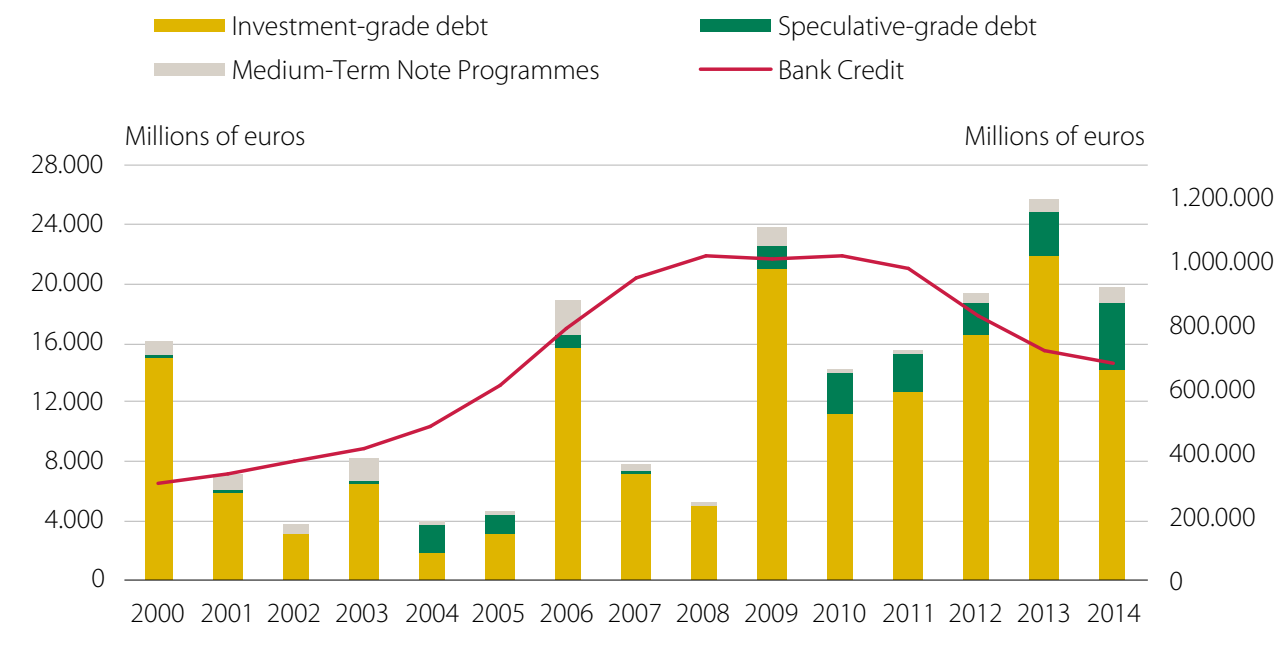

Source: Dealogic and Bank of Spain.

However, financial institutions still issue the largest volumes of debt; in 2014, Spanish banks issued 40,108,000 euros compared to 15,433,000 euros from non-financial entities ${ }^{19}$.

It is not easy to obtain data on the total volume of outstanding debt issued by Spanish companies. The Bank for International Settlements estimated that in June 2014 the balance amounted to 1,254,000 million dollars, of which 98\% were from financial institutions and the rest from non-financial businesses. Similarly, the statistics published by this agency show that, while outstanding debt from financial institutions had decreased by $21 \%$ between December 2011 and June 2014, the outstanding balance of non-financial companies had increased by $74 \%$ over the same period.

There are also no references that indicate the creditworthiness of the outstanding debt, but a first approximation could be obtained from the qualified issue portfolio by one of the three major rating agencies. In late July 2014, Fitch Ratings maintained 600 qualified issues, 439 corresponding to financial institutions and 161 to non-financial ones.

18 Source: Bank of Spain.

19 Source: Dealogic. Issues by financial institutions include corporate debt issues, credit notes and MTN programmes. Issues by non-financial institutions include corporate debt issues and MTN programs. 


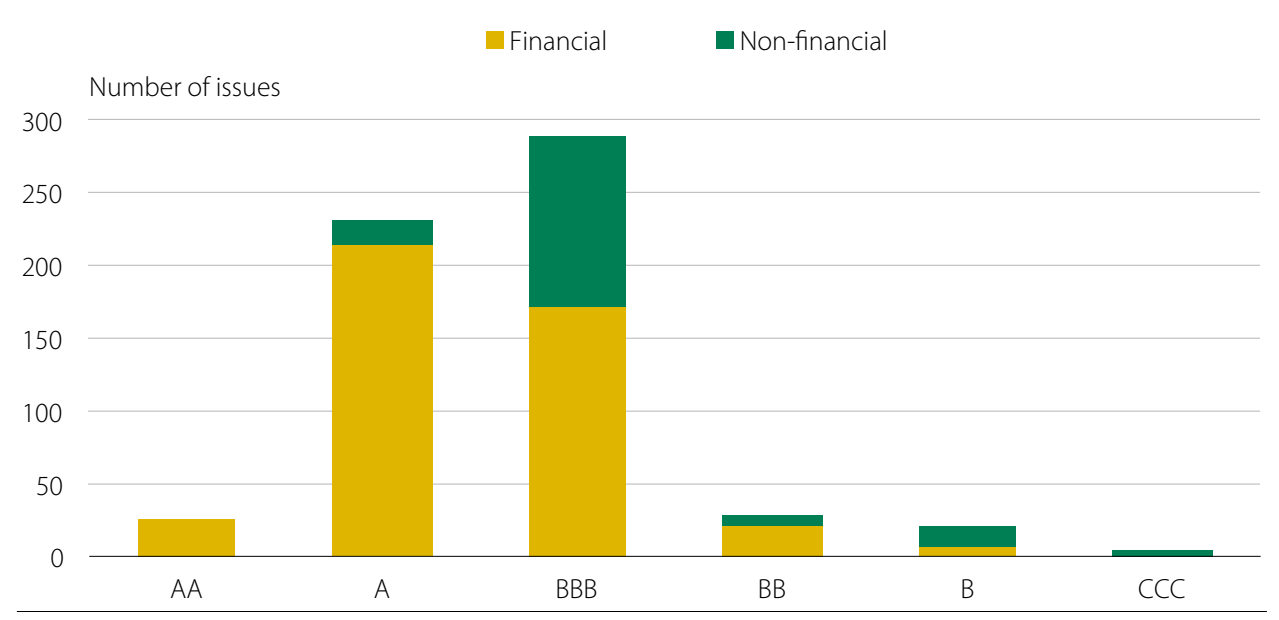

Source: FitchRatings.

The distribution of these qualifications is shown in figure 6. The low number of issues with AAA rating is noteworthy; it was much higher before the crisis. Its decline has been due to the direct impact of the crisis on Spanish business, particularly on the financial sector, as well as the effect arising from the allocation of BBB+ rating to the Kingdom of Spain, which imposed a ceiling on almost all domestic issuers. Despite this, the bulk of Spanish corporate debt is within the investment grade and corresponds mostly to financial institutions. Lastly, we note that the number of issues within the range of speculative debt is very small and is shared between financial and non-financial companies.

However, Spanish speculative debt has increased gradually in recent years. Specifically, between 2011 and 2014 Spanish high-yield bond issues grew by $145 \%$, reaching 5,294 million euros in $2014^{20}$. Non-financial firms have been increasing their presence in the debt markets, especially industrial and civil engineering companies, who have resorted to this resource to finance working capital to make the investments necessary for organic growth (see Chart 7).

\section{Issue of speculative debt by sector in 2014}

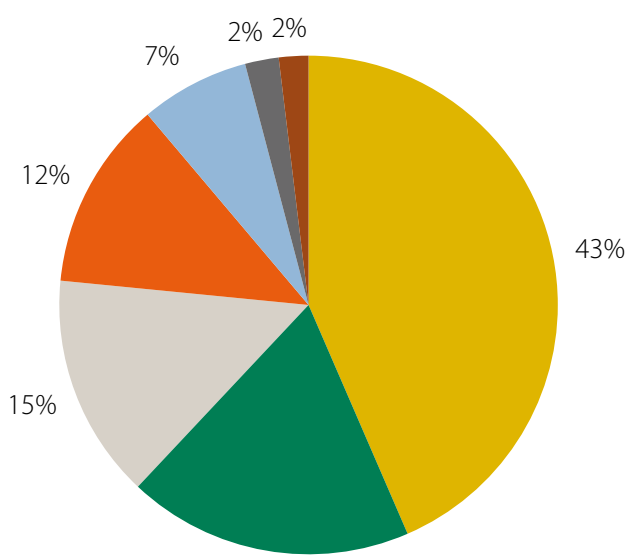

Engineering

- Health

- Financial

- Construction

- Industrial

- Gaming

- Telecommunications

$19 \%$

Source: Dealogic. 



\section{Specific features of the seconday market for high-yield bonds}

The dynamism of high-yield bond issues has allowed this segment to gain critical mass in secondary markets where significant growth can be seen in the number of completed transactions and price increases. All this helps to generate a perception among investors and intermediaries that, in recent years, the channels of speculative debt trading have matured and that their performance has improved. However, these markets retain a high level of risk that investors should take into consideration because, in times of instability, their activity can be dramatically reduced, preventing them from dissolving their positions in an orderly manner and affecting the balance sheet value of their investments.

\subsection{Characteristics of secondary market operations}

The fixed income bond as a whole, and speculative debt is no exception, has no organized markets of reference because many of the transactions are still carried out via bilateral contacts in OTC markets. Specifically, it is estimated that $90 \%$ of the volume traded in the US bond market is through direct contacts between professional investors acting on their own or financial intermediaries operating in the market on behalf of their clients.

Bilateral trading can be developed through a variety of media, ranging from phone to electronic trading platforms, via individual portals built by trading houses in which sales prices are requested. According to a survey conducted in 2012 by the Association for Financial Markets in Europe (AFME) among institutional investors, $35 \%$ of transactions in the secondary market of fixed income securities are made via electronic media and the rest via telephone contacts.

Electronic trading based on the order book, characteristic of organized variable income markets, is also used in some fixed income trading systems, especially those aimed at retail investors, such as the Electronic Trading System (SEND) that is operated by the Spanish Stock Markets (BME). In this case, traded securities often have liquidity providers; i.e. intermediaries who are required to provide minimum counterpart volumes during a session. However, the specific weight of the retail segment in the secondary bond markets is residual, since the markets are essentially focused on trade between institutional agents.

The preponderance of wholesale trading is a contributory factor to fixed income operations in secondary markets being much fewer when compared to other mar- 
kets, such as the variable income market, but of a larger size ${ }^{21}$. So, while the average size of share trading operations on the stock exchanges was around 6,520 euros in $2013^{22}$, in European fixed income markets they mostly consisted of transactions with an average unit size between one and two million euros, with many being over five million euros ${ }^{23}$.

This difference is further accentuated when the high-yield bond segment is taken into account, as shown for example, by the data supplied by investors through the mandatory TRACE reporting mechanism (Trade Reporting and Compliance Engine) in effect in the United States. While it is true that in this segment there is a significant number of relatively small operations that follow the usual practice among market makers of chopping up their security inventories to respond to requests made by their customers ${ }^{24}$, the most important operations segment was that with an amount of between one and twenty-five million dollars.

Trading frequency is another distinguishing feature when compared to variable income: it is much lower in the secondary bond markets. For example, a report by the TABB Group in 2012 for the AFME 25 includes a comparison of fixed and variable income trading of five European companies from among the most active in the financial markets ${ }^{26}$. The results showed that, between the last quarter of 2011 and the first quarter of 2012, the number of operations that were performed with shares of these companies was 167 times higher than those made with debt securities. In one case involving a large issuer, Deutsche Telekom, for each transaction with one of its bonds there were 3,500 transactions in shares.

One might think that high-yield bonds are traded less frequently than other assets considered to be less risky and whose issues generally are larger, for example, the securities or issuer portfolio covered bonds. However, it is not necessarily so. As mentioned in table 2, the percentage of high-yield bonds traded under 20 times a month during the period July 2010-June 2011 was clearly inferior to those securities and even to the whole amount of corporate debt.

21 The size of the operations in the fixed income markets is also influenced by the larger size of the issues and the lower number of initial subscribers, which, coupled with the difficult interchangeability of securities, often requires investors to buy or sell their entire positions of a certain value. Also, the size of the variable income operations must take into account the HFT growth, the operations of which are characterised by the launching of a large number of small orders in a short period of time.

22 According to data published by the World Federation of Exchanges, available at http://www.worldexchanges.org/files/2013_WFE_Market_Highlights.pdf

23 Data included in the report of the International Capital Market Association (ICMA) «Economic Importance of Corporate Bond Markets», published in 2013.

24 TRACE recorded a daily average of 8,550 transactions worth less than \$100,000 in 2013.

25 TABB Group (2012). «MiFID II and Fixed-Income Price Transparency: Panacea or Problem?»

26 The companies included in the sample were: France Telecom SA, Belgacom SA, Deutsche Telekom AG, Koninklijke KPN NV and Vivendi SA 


\begin{tabular}{lrrrrrr}
\hline & $\begin{array}{r}<0 \\
\text { transactions }\end{array}$ & $\begin{array}{r}20-50 \\
\text { transactions }\end{array}$ & $\begin{array}{r}\mathbf{5 0 - 1 0 0} \\
\text { transactions }\end{array}$ & $\begin{array}{r}100-200 \\
\text { transactions }\end{array}$ & $\begin{array}{r}\mathbf{2 0 0 - 4 0 0} \\
\text { transactions }\end{array}$ & $\begin{array}{r}>400 \\
\text { transactions }\end{array}$ \\
\hline Public debt & $7,6 \%$ & $1,32 \%$ & $7,82 \%$ & $22,95 \%$ & $29,97 \%$ & $30,34 \%$ \\
\hline Corporate debt & $63,80 \%$ & $21,13 \%$ & $10,10 \%$ & $4,38 \%$ & $0,59 \%$ & $0 \%$ \\
\hline Covered Bonds & $82,17 \%$ & $14,33 \%$ & $2,96 \%$ & $0,47 \%$ & $0 \%$ & $0,08 \%$ \\
\hline High-yield bonds & $53,83 \%$ & $32,33 \%$ & $10,42 \%$ & $2,5 \%$ & $0,92 \%$ & $0 \%$ \\
\hline Securitisation & $99,7 \%$ & $0,3 \%$ & $0 \%$ & $0 \%$ & $0 \%$ & $0 \%$ \\
\hline
\end{tabular}

Source: AFME.

Among the possible reasons for this difference, the AFME notes that high-yield bonds have a higher proportion of investors who manage their portfolios actively, while among buyers of other types of securities, investors with a long-term perspective tend to predominate; these are more likely to hold the investment until maturity. Moreover, assets with low ratings tend to circulate more than other private fixed income assets with better ratings, as they are much more sensitive to changes in macroeconomic conditions or the market and the related issuer.

Despite the greater rotation observed in high-yield bonds compared to other financial instruments, currently, many asset managers are opting to hold such securities in their portfolios until maturity because they are not sure they can replace them by a new issue which, with the same level of risk or less, would offer the same levels of profitability. This is because of the progressive decline in interest rates offered by issuers of this kind of debt because of the growing demand for it.

Within speculative-grade debt, bonds with higher ratings are usually traded more frequently ${ }^{27}$, normally with a price around par, except for small fluctuations due to shifts in the interest rates.

It is difficult to estimate the total annual volume of transactions of high-yield bonds in the secondary markets and consequently, it is difficult to study with sufficient thoroughness their evolution and the factors that affect it. One of the few sources of data available is FINRA (Financial Industry Regulatory Authority), a US broker industry association which acts as a self-regulatory organization, recognized by the SEC, in the field of intermediaries and markets. Among other functions, this organization must monitor the compliance with transparency obligations under the TRACE operating system mentioned above. According to data published by FINRA, during $2014^{28}$, the average daily trading volume amounted to 10,693 million dollars.

27 In the United States in 2013, 56\% of transactions in this segment involved bonds rated BB or B.

28 This figure is from the third quarter of 2014, although the average daily trading volumes over the previous quarters were very similar. 
If we assume an average of 251 trading days, the annual volume would be around 2.7 trillion dollars ${ }^{29}$.

\subsection{Behaviour of high-yield bonds in secondary markets}

A good approximation for the evolution of the secondary market for high-yield bonds is given by analysing the behaviour of some of the most important indexes that are referenced in this segment. Specifically, in this section, the following indices are used: High Yield US Master II, which replicates the performance of speculative grade corporate debt issued in dollars in the United States; its counterpart for the European market, the High Yield Euro Master Index and the US Corporate Master Index, which shows the behaviour of investment-grade corporate debt issued in the US, all constructed by Bank of America-Merry Lynch.

The market value of high-yield bonds has undergone major changes conditioned by the different economic scenarios occurring in recent years (see Figure 8). During the years of economic growth, this market segment showed a certain sluggishness because of investors' preference for other securities with better credit ratings and attractive yields such as securitised issues. In 2008, bond prices dropped significantly by $8.3 \%$ in the US market and $13.5 \%$ in Europe, mainly because many investors replaced this kind of product by others considered safer, due to the uncertainty prevailing in financial markets. However, unlike other markets, high-yield bonds began to recover in 2009 and have since shown positive returns.

\section{Evolution of the performance of European and US indices of high-yield bonds}

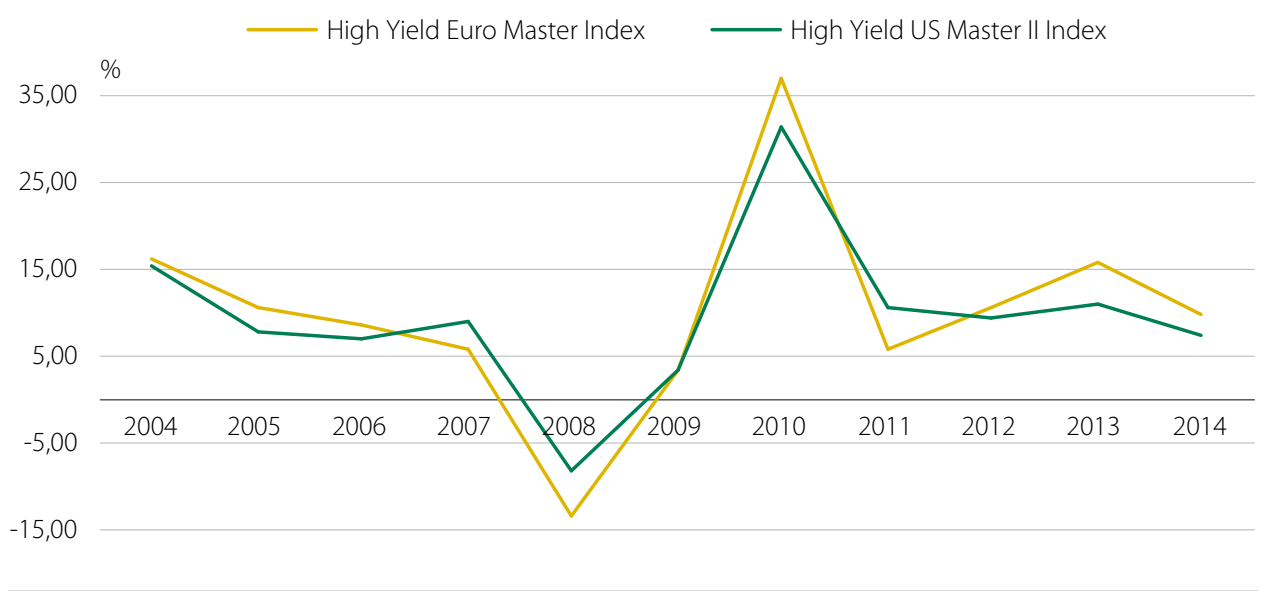

Source: Bank of America-Merry Lynch.

It is worth noting that in recent years the European market is giving higher returns than the US market. Thus, in 2014, the average yield of the European index was

These data do not include transactions of convertible fixed income bonds or the allocations made in the primary market and sold on the first day of trading by a single subscriber or by the global coordinators of a placement. 
9.8\%, compared with $7.4 \%$ recorded across the Atlantic. Since 2009 it has an accumulated growth of $103.7 \%$ compared with $89.1 \%$ for its American counterpart.

\section{Lower volatility on reducing the level of market uncertainty}

The overall profitability of speculative debt is given by two components, the coupon received by investors and the price fixed by the market. The higher return offered by this type of security provides a cushion against market fluctuations thus allowing speculative debt to achieve lower levels of volatility than investment debt in ordinary market conditions.

Similarly, the market price of this debt is less sensitive to interest rate movements. The reason is that the coupon offered by these securities is obtained from the real risk-free interest rate plus a premium obtained from a number of considerations, among which are the credit risk of the issuer and the forecast inflation. The weighting of the risk premium on the overall coupon paid by these entities is higher than the benchmark risk-free interest rate used and, therefore, the market price will be less affected by monetary policy decisions than other debt of higher credit quality in which the monetary component is a more significant factor in their remuneration.

Figure 9 explains this. During the periods of greater stability of financial markets, up to 2007 and after 2010, the US high-yield bonds recorded lower volatility than bonds of higher credit quality - between $1.5 \%$ and $4.5 \%$ - which represents around one percentage point less than all other corporate debt.

In contrast, between 2007 and 2009, speculative debt showed higher volatility than other corporate debt because investors mostly left these risky types of investments and took refuge in safer securities such as sovereign debt of certain countries. In particular, the volatility of the US speculative debt was as high as $10.8 \%$, while the remaining corporate debt did not exceed $8 \%$.

Volatility of US corporate debt: 2004-2014

FIGURE 9

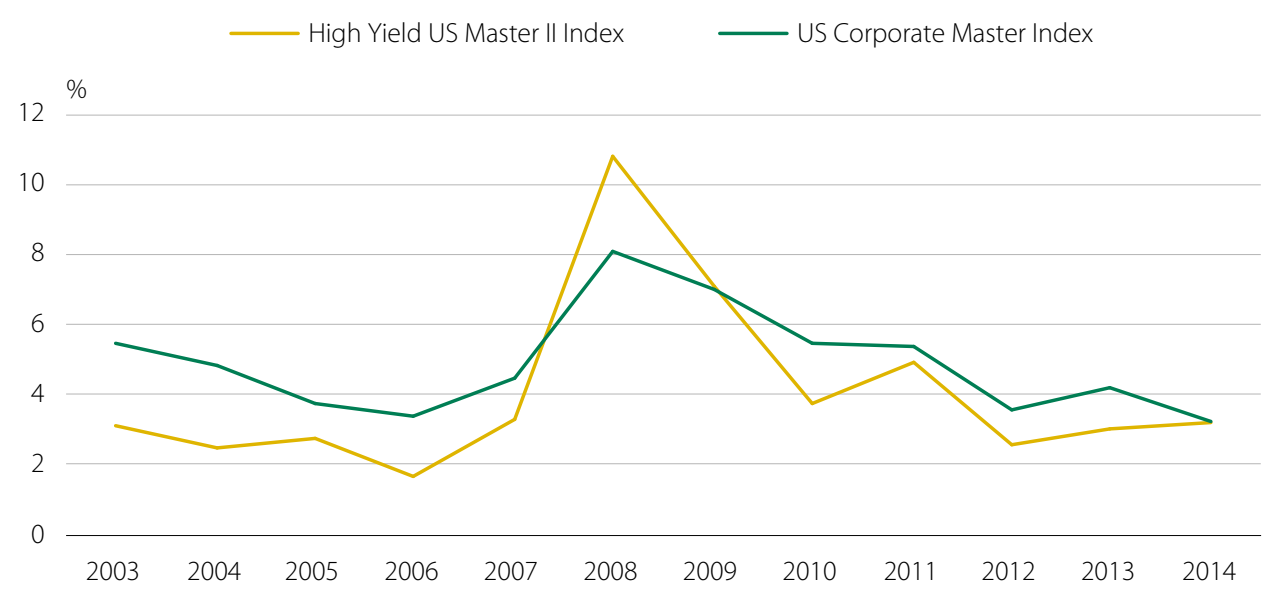

Source: Bank of America-Merry Lynch and proprietary research.

Volatility is calculated as the standard deviation of the daily index yields that have been annualized based on the actual trading days. 
Currently, investors are doing the opposite, moving from public debt to high-yield bonds, seeking higher returns for their portfolios and diversification of financial products on their balance sheets that are suitable for the current economic and financial conditions.

One of the statistical measures most taken into account by investors when assessing the suitability of the composition of an investment portfolio is the correlation ${ }^{30} \mathrm{ex}^{-}$ isting between the securities it contains. The less correlated a portfolio's assets, the more effective the risk reduction of incurring losses and the greater the profit that can be earned through diversification. Correlations among financial assets change with business movements or variations in the economic and financial situations.

Numerous studies have analysed the correlation of high-yield bonds with other assets during different economic periods ${ }^{31}$. It was found that high-yield bonds have a significant correlation with the rest of corporate debt. Furthermore, it has been shown that there exists a significant positive correlation with variable-income securities, sometimes even higher than that obtained for investment-grade debt, but only during the years of stability. This is because speculative debt is more dependent on the company's evolution, as is the case with shares, than higher quality fixed-income products.

However, in periods of uncertainty, as occurred between 2008 and 2011, the link between both types of values is much smaller and it can be seen that the market behaviour of these two sets of securities is clearly different. Specifically, during those years, speculative debt lost less value than shares and recovered earlier. A key factor that largely explains this uneven development between 2008 and 2011 is the fact that speculative-grade bonds continued to provide investors profitability through periodic coupon payments, while in the case of shares, in addition to the price drop, the distribution of dividends was suspended in many cases to ensure the company had enough cash in an environment where accessing external finance, especially bank financing, was more difficult.

The correlation between speculative debt and public debt is less when compared with the other two groups of financial assets although, in recent years, they have shown a high degree of substitutability within investors' portfolios. Thus, between 2008 and 2010, investments shifted towards securities that were considered safe at a time of great uncertainty with regards to the economy and the situation of financial institutions, leading to an increase in prices for public debt and a decrease in speculative debt prices. After 2011, the relationship between these two financial products remained but in reverse; the quest for profitability in the face of low interest rates offered by safe assets in a perceived context of lower risk has favoured a certain amount of replacement of positions in government debt for high-yield bond positions.

30 The correlation measures the relationship between two financial assets and their degree of inter-dependence.

31 Amongst the most recent, Tuysuz, S (2013), «Conditional Correlations between Stock Index, Investment Grade Yield, High Yield and Commodities (Gold and Oil) during Stable and Crisis Periods». International Journal of Economics and Finance; Vol. 5, No. 9; 2013,

Fridson, M. S.(2010). «How Research from the High-Yield Market Can Enhance Equity Analysis», available at http://www.cfapubs.org/doi/pdf/10.2469/cp.v27.n2.2, o

Reilly, F. K., Wright, D. J., \& Gentry, J. A. (2009). Historic changes in the high yield bond market. Journal of Applied Corporate Finance, 21(3), 65-79. 


\section{Potential sources of risk in the high-yield bonds market}

The rapid growth in the high-yield bond market has raised doubts in different institutional settings as to whether investors are correctly assessing the risks of including these high-yield, high-risk assets in their portfolios.

The International Monetary Fund (IMF) in its Global Financial Stability Report of April 2014, noted that the pressure of demand was affecting the quality standards of the securities issued, as happened during the years before the crisis, and this could contribute, as happened in the past, to higher levels of default and lower rates of recovery in the event of a stagnation or recession scenario.

Also, several regulators such as the Bank of England or the US Federal Reserve ${ }^{32}$ have declared their intention to pay special attention to how this financial product evolves to ensure that investors really understand the risk assumed by acquiring them, that sufficient capital is being accrued and that they do not assume excessive exposures that might compromise the stability of their balance sheets. The regulators' concern is also largely explained by the fact that more and more private investors are accessing speculative-grade debt indirectly by acquiring shares of collective investment schemes, in which the managers include these kinds of securities in their portfolios to deliver attractive returns to customers.

Among the potential risks that may not be considered sufficiently by the financial markets would be the deteriorating quality of issues, their low liquidity in the secondary market, the impact of a potential increase in interest rates and the effect of the new regulatory framework based on Basel III. More specifically, we must also consider the risks associated with issues in emerging economies that are generating significant interest among investors.

\section{Deterioration in the quality of high-yield bonds}

In recent years, the increasing demand for speculative bonds in the financial markets has contributed to the decline of the guarantees and the scope of the covenants. For example, some issues in the United States have removed the bank intervention clause and, in the event of the issuer's financial position deteriorating, they allow buybacks or incorporate coupon or principal payment clauses, in cash or securities, at the issuer's discretion 33 .

32 Notice published by the Bank of England on July 25, 2014 on Investing in Corporate Bond Funds. Address by the President of the Federal Reserve to the International Monetary Fund on July 2, 2014.

33 In Spain, a reduction in the extent of covenants has also been observed in some cases. For example, a bond issue by ACS in October 2013 included an early redemption option for lberdrola shares in favour of 
The result of the gradual easing of securities issuance terms, as regards extending the term of the securities, decreasing the interest rate paid or reducing the scope of the covenants, is an increase in issues rated below BB. In the American market, these issues went from $42.7 \%$ of the total in April 2013, to 56.5\% in April 2014.

\section{Limited liquidity of the secondary market for high-yield bonds}

Investors may not be taking sufficiently into account the peculiarities of secondary markets in which such securities are traded. As noted, unlike variable income bonds, there are no organized markets of reference for fixed income bonds and, in practice, most of the transactions are conducted in OTC markets through bilateral contacts. Such markets commonly provide little information about the terms on which the sale has been concluded, barely contributing to the definition of prices in future operations and making it more difficult for investors to evaluate their portfolios. The pre-trade transparency is also low, so investors may incur considerable expense searching for information on supply and demand prices. Furthermore, by their very nature, high-yield bonds tend to be illiquid in the secondary market. As revealed in the height of the recent financial crisis, opacity and reduced market liquidity may expose investors to higher levels of volatility. Regulators are exploring various ways to improve the functioning of the OTC fixed income markets. One of the most important measures is the introduction of pre- and post-trade transparency requirements 34 .

In relation to this, last May the European Union completed the laborious process of reviewing the Financial Instrument Markets Directive ${ }^{35}$, approving a new directive, known as MiFID II ${ }^{36}$, and a regulation, known as MiFIR ${ }^{37}$, which provide for a wide range of measures to improve the level of transparency of these operations and which will affect, amongst other instruments, the high-yield bond segment. These rules will apply generally from 2017.

\section{Future scenarios of interest rate rises}

Although monetary policies still have a clearly expansionary nature in the major industrialized countries, some of them have already begun to consider the gradual abandonment of some of the unconventional measures widely used during the cri-

the investors. However, the issuer has reserved the right to deliver shares, cash or a combination of these if the option is exercised.

34 The article «Mandatory transparency schemes in the secondary market for speculative debt» Martin M.R. (2014), published in the CNMV Bulletin, Quarter III 2014, delves into the effect of the transparency requirements in the functioning of markets for speculative debt.

35 Directive 2004/39/EC of the European Parliament and of the Council of 21 April 2004 on financial instrument markets amending Council Directives 85/611/EEC and 93/6/EEC and Directive 2000/12/EC of the European Parliament and by which Council Directive $93 / 22 / \mathrm{EEC}$ is repealed

36 Directive 2014/65/EU of the European Parliament and of the Council of 15 May 2014 on financial instrument markets which amends Directive 2002/92/EC and Directive 2011/61/EU

37 EU Regulation No. 600/2014 of the European Parliament and of the Council of 15 May 2014 on financial instrument markets which amends EU Regulation No. 648/2012/EU 
sis. This is not the case is the Eurozone where the ECB has intensified the expansionary policies by implementing unconventional measures that it had not previously used. Nevertheless, in the US and in the UK the improving economy has opened the door to the progressive withdrawal of monetary stimulus, creating a new scenario in which investors cannot rule out that, at some point, there will be a rise in official interest rates.

Hence, during the last year some regulators have begun to assess the potential effects of interest rate increases. An economic scenario with higher interest rates has several implications for investors that currently hold high-yield bonds in their portfolios.

The first consequence would be a drop in prices in security markets, as occurred in June 2013 when the progressive withdrawal of monetary instruments for stimulating the economy was announced by the American Federal Reserve. In the analysis carried out by rating agency Fitch Ratings ${ }^{3}{ }^{8}$, a rise of 5 obp in the interest rate would cause a $4 \%$ loss in the market value of a bond with BBB rating. In the case of speculative debt, market reaction would be more pronounced because of the higher credit risk associated with these securities and the prevalence of fixed interest payments.

Simultaneously, the fall in market prices would result in a lower number of operations, exacerbating the limited activity that this market segment displays even under normal conditions. Successfully completed transactions would be at even lower prices, which would help to further drag down the profitability of these securities.

Investors with high yield-bonds in their trading portfolio, particularly dealers and market makers, would not only find it difficult to act in the market, but that the fair market value of their portfolios, valued at market prices with little activity and falling prices, would force them to increase capital endowments and improve liquidity ratios.

Buyers with a greater intention to retain the security - investment funds, insurance companies - would also be affected in this new scenario. The investors who had renewed their bond portfolio in recent years would suffer a relative decline in the profitability of these investments in relation to that achieved by other market agents, and therefore this would affect the compensation that they could offer to holders. Additionally, the settlement value of these financial products would be affected since, in general, it is derived from the market value of its assets, affecting holders' reimbursement.

Lastly, it should be noted that the context of low interest rates and growing acceptance of these securities has meant that issuers generally exercise their purchase option after a few years in order to replace the outstanding debt by another with lower cost or more favourable conditions. However, a rise in interest rates could discourage issuers from exercising this option, so some investors may find that their portfolios contain securities for a longer term than initially planned. This would also

FitchRatings (2012). «The Bond Bubble: Risks and Mitigants». 
affect the bond yield curve and, therefore, its liquidity because its attractiveness would decrease considerably.

\section{Impact of the new regulatory frameworks}

Basel $2.5^{39}$ introduced amendments regarding how trading portfolios are treated in order to align the capital requirements of the exposures held in the trading book with those of the investment book, thus eliminating the possibility of financial institutions arbitrating between the two.

As a consequence of increased capital requirements for the portfolios held in the trading book, market makers have been forced to reduce the volume of securities held in their inventories. The American Federal Reserve estimates that intermediaries of the US fixed income bond market have gone from holding \$ 250 million in securities in 2007 to only 57 in 2014 . This may increase the illiquidity of the fixedincome bond markets, which would lead to greater volatility and would impact on market valuations of assets in trading portfolios, forcing them to once again increase the capital endowments of these agents and starting the cycle over again.

The disappearance of many of the market makers would raise the question of which other agent might assume the role of providing liquidity to the fixed-income bond markets. Given that most of these securities are to be found on the balance sheets of institutional investors, largely the funds, these would be seen as a natural source of liquidity, with the incentive to increase their income through sales margins. Moreover, unlike market makers, fund managers do not need to refinance short-term investment portfolios because they are funded by the participants whose positions are in the long term, which would add stability to the system at times of liquidity crisis.

\section{The attractiveness of emerging country debt}

In 2013, China overtook the United States as the largest issuer of corporate debt worldwide. According to estimates published by Standard \& Poors ${ }^{40}$, the Asian country has outstanding securities worth \$ 14.2 trillion, while the United States has $\$ 13.1$ trillion. This new scenario introduces an additional risk factor because the credit quality of Chinese companies is lower than that of European or American ones and a potential deterioration of the US economy could affect the debt market globally.

Moreover, also according to estimates by the aforementioned rating agency, between $25 \%$ and $30 \%$ of the securities issued by Chinese companies would be ac-

\footnotetext{
39 In Europe the provisions of Basel 2.5 in this regard were incorporated in Directive 2010/76/EU of the European Parliament and of the Council of 24 November 2010 amending Directives 2006/48 / EC and 2006/49 / EC with regard to capital requirements for the trading portfolio and for re-securitisations, and the supervisory review of remuneration policies

40 Standard\&Poors (2014): «Credit Shift: As Global Corporate Borrowers Seek \$60 Trillion, Asia-Pacific Debt Will Overtake U.S. And Europe Combined»
} 
quired by shadow banking entities, whose excess liquidity would be reheating the Chinese debt market. In absolute terms, this means that about $10 \%$ of global corporate debt is concentrated in investors that are outside the scope of the supervisory authorities of the Chinese banking system.

The risk comes not only from China but, in general, from emerging countries whose companies have used the low interest rate environment to issue debt at competitive market prices. The IMF41 estimates that, apart from China, countries like Bulgaria, Hungary and Malaysia, recorded volumes of corporate debt at GDP level. In a scenario of lower economic growth, companies in these countries might be more vulnerable. If their income decreases, they would find it difficult to refinance their debts or pay principal and interest, affecting a large number of local and international investors.

41 Global Financial Stability Report, April 2014. 



\section{Conclusions}

The macro-financial scenario and the confluence of interests between institutional investors and companies, both financial and non-financial, have driven the growth of corporate debt markets. This expansion does not only affect the market segment that binds the issues whose credit rating is within the so-called investment grade, but also those issues classified as speculative debt.

The high-yield bonds have become an alternative for investors who have traditionally shown some intention of holding the securities in which they invest for some time. Besides offering attractive returns in the current environment of low interest rates, they allow portfolio diversification by incorporating economic exposures of a less conventional nature and in riskier sectors; despite this, they have shown surprising resilience in the scenarios of turbulence and uncertainty of recent years.

The current macroeconomic and financial scenario, which still warns of significant uncertainty but with a considerable improvement compared with the peak period of the financial crisis, does not eliminate the risk inherent in this debt market segment. Credit risk may have passed into the background because of the low levels of arrears and default shown by the issuers of speculative debt, but it remains dormant and can become active if signs of economic stagnation or recession appear. It may be particularly severe if it occurs in emerging countries, with productive sectors having excessive debt levels and lesser capacity for recovery in the short term.

One of the main risks to consider is a future rise in interest rates; this is unlikely in Europe but it cannot be ruled out in the United States where the monetary authorities are adopting new policies. If it does occur, the increase would affect both the current holders of these securities as well as the issuers. In the case of the former, the opportunity cost implied by maintaining securities in the portfolio acquired in recent years, along with a predictable price decline in the secondary markets, clearly depicts a losing combination. In the case of the latter, the costs of accessing debt markets would increase and not all companies would be able to bear such costs.

If new economic imbalances occur, secondary markets for speculative debt may not be a stabilizing element. In general, they are very sensitive to change and uncertainty and, therefore, investors are exposed to higher levels of volatility. Also, in times of high uncertainty, these markets fail, preventing the formation of prices, necessary for evaluating portfolios or the orderly withdrawal of investors from their positions.

Despite the risks inherent in this market segment, at an institutional level there is a clear interest in consolidating corporate debt markets as a source of additional funding available to companies. Normalising the access of SMEs to debt markets in 
order to thereby reduce their dependence on bank credit is considered particularly positive.

To this end, many initiatives are being undertaken ${ }^{42}$ with the aim of coordinating economic policies to channel resources from different sectors of the economy, investment funds, pension plans, insurance and even individual savings, towards financing companies with solvent projects and growth potential. This is yet another reason to consider the risks associated with some financial instruments, including high-yield bonds, which may contribute to the aim pursued.

42 In this regard, we should mention work on the development of corporate bond markets by the World Bank, the FSB and the International Organization of Securities Commissions. 


\section{Bibliography}

AFME and O. Wyman (2013) «Unlocking funding for European investment and growth». Available at www.afme.eu/unlocking-funding-for-European-investmentand-growth.

Allianz Global Investors (2013). «The Evolution of High-Yield Bonds into a Vital Asset Class». Available at

Bessembinder, H.,W Maxwell and K.Venkataraman. (2006), «Market Transparency, Liquidity Externalities, and Institutional Trading Costs in Corporate Bonds» available at http://home.business.utah.edu/hank.bessembinder/publications/bondtransparency.pdf .

Bessembinder H., W. Maxwell (2008) Transparency and the corporate bond market. Available at http://home.business.utah.edu/hank.bessembinder/publications/transparencyandbondmarket.pdf

Comisión Nacional del Mercado de Valores (2012). «Securities markets and their agents: situation and outlook». Bulletin of the CNMV, Quarter III, pp. 9-68. Available at http://www.cnmv.es/DocPortal/Publicaciones/Boletin/BTIII2012_Web.pdf

Deutsche Bank (2013). «Corporate Bond Issuance in Europe: Where do we stand and where are we heading». Available at http://www.dbresearch.com/PROD/DBR INTERNET_EN-PROD/PRODoooooooooo300834/Corporate+bond+issuance+in+Eur ope\%3A+Where+do+we+stand+and+where+are+we+heading\%3F.pdf

Edwards, A., L. Harris and M. Piwowar (2007), «Corporate Bond Market Transparency and Transaction Costs». Journal of Finance 62 (3), 1421-1451

FichRatings (2012), «The Bond Bubble: Risks and Mitigants». Available at http:// www.sifma.org/uploadedfiles/for_members/thought_leader_library/2012/fitchbond-bubble.pdf?n=34035

FitchRatings (2014), «The Cost of Economic Recovery: Rating Stabilisation but «BBB» the New Form», available at https://www.fitchratings.com/creditdesk/press _ releases/detail.cfm?pr_id $=815873 \& \mathrm{~cm}_{-}$sp=homepage-_-Featured_Content_Archive-Global Rating Trend Shows 'BBB' Level Convergence

International Monetary Fund (2014). «Global Financial Stability Report, April 2014». Available at http://www.imf.org/external/pubs/FT/GFSR/2014/o1/pdf/text.pdf 
Fridson, M. S.(2010). «How Research from the High-Yield Market Can Enhance Equity Analysis», available at http://www.cfapubs.org/doi/pdf/10.2469/cp.v27.n2.2

Goldstein, M., E. Hotchkiss and E. Sirri (2007), «Transparency and Liquidity: A Controlled Experiment on Corporate Bonds». Review of Financial Studies 20 (2), 235-273

International Capital Market Association (2013) «Economic importance of the Corporate Bond Markets», available at http://www.google.es/url?sa=t\&rct=j\&q=\&esrc=s $\&$ frm $=1$ \& source $=$ web $\& c d=1 \& c a d=$ rja\&ved $=0 C D M Q F j A A \& u r l=h t t p \% 3 A \% 2 F \% 2 F w$ ww.icmagroup.org\%2Fassets\%2Fdocuments\%2FMedia\%2FBrochures\%2F2O13\%2 FCorporate-Bond-Markets-March-2013.pdf\&ei=FPBkUresO8ap7QbqyoDYDg\&usg= AFQjCNHauzvTKRbjoVQQWQFMwagIYPVOkw

Proskauer (2013), High Yield Trends, available at http://www.proskauer.com/files/ uploads/2013-High-Yield-Bond-Study.pdf

Reilly, F. K., Wright, D. J., \& Gentry, J. A. (2009). Historic changes in the high yield bond market. Journal of Applied Corporate Finance, 21(3), 65-79

Standard\&Poors (2013). "2013 Annual Global Corporate Default Study And Rating Transitions» available at https://www.globalcreditportal.com/ratingsdirect/renderArticle.do?articleId $=1279609 \&$ SctArtId=222966\&from=CM\&nsl_code=LIME

TABB Group (2012), «MiFID II and Fixed-Income Price Transparency: Panacea or Problem?» available at http://www.afme.eu/workarea/downloadasset.aspx?id=6165 

